\title{
Grid tied PV system using modular multilevel inverter
}

\author{
Sujitha N., Partha Sarathi Subudhi, Krithiga S., S. Angalaeswari, T. Deepa, D.Subbulekshmi \\ School of Electrical Engineering, Vellore Institute of Technology, India
}

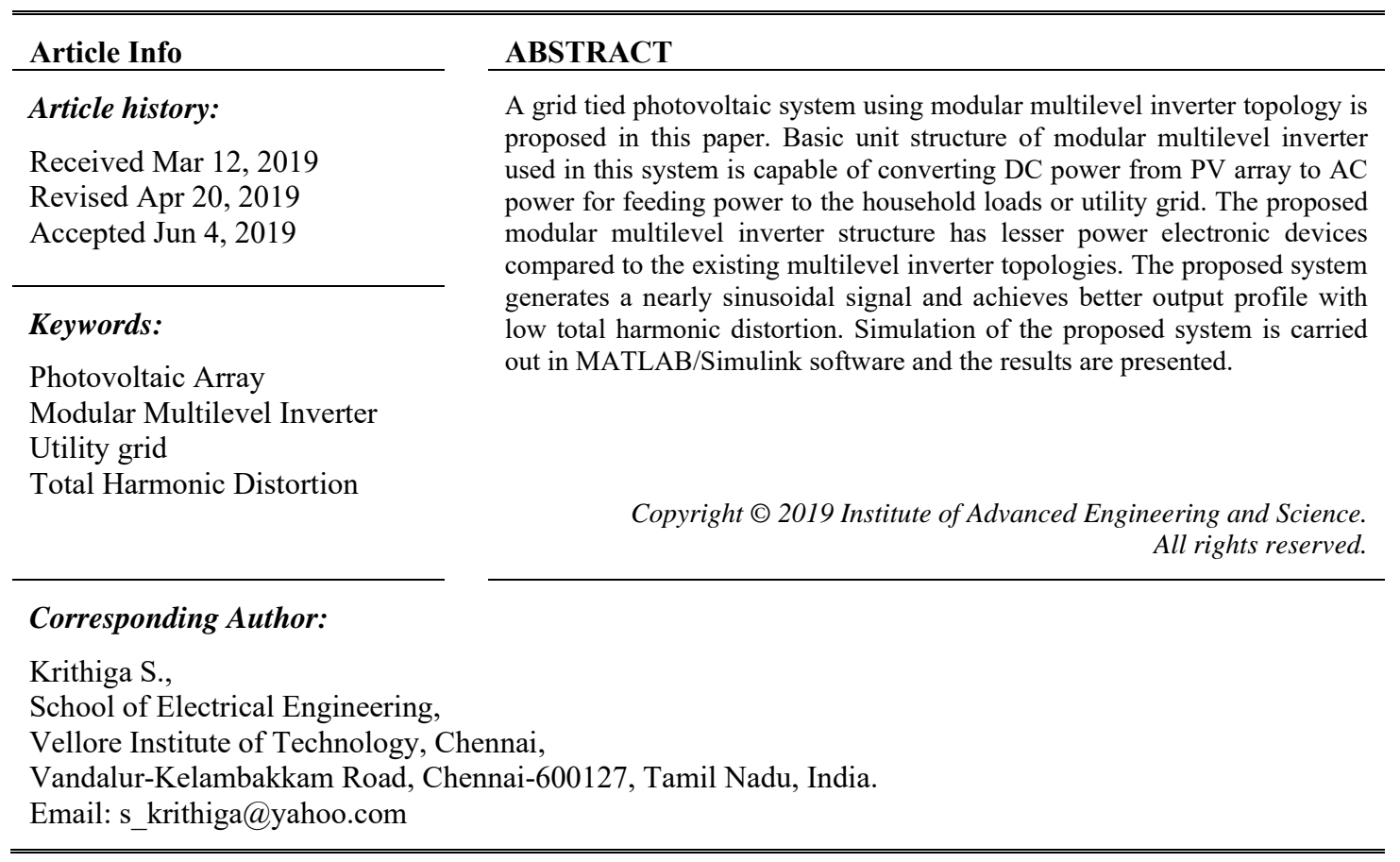

\section{INTRODUCTION}

Photovoltaic (PV) systems are booming in the renewable energy market due to its clean and abundantly available nature $[1,2]$. Also, solar energy is easily tapped and converted into electricity which is the added advantage of PV array over other renewable energy sources [3]. Due to the intermittent nature of the PV array, power electronic interface is needed in the standalone and grid tied PV systems for obtaining the desired output [4]. For grid tied PV system, power electronic inverters are utilized as the interface to convert the generated dc power from the PV array into ac power to feed the utility grid [5-9].

Basic inverter generates a squarewave output which is considered to have higher harmonic content. Thus, large size filter has to be employed to obtain pure sinusoidal waveform inorder to feed the PV generated power to the grid. Also, this inverter has high dv/dt stress and harmonic distortion in the output waveform. To overcome these problems, multilevel inverters were developed.

Multilevel inverter (MLI) is popular among industrial and research sectors due to its advantages like improved output voltage profile with low $\mathrm{dv} / \mathrm{dt}$ and low common mode voltages $[10,11]$. The output voltage of MLI has low distortion and low harmonic content which reduces the size and cost of the filter and the level of electromagnetic interference (EMI) [12]. The three basic MLI topologies are diode clamped MLI, flying capacitor MLI and cascaded MLI [13-15]. As the number of levels of output voltage increases, these topologies require increased number of switches, diodes and capacitors which eventually increases the cost, volume and control complexity [16-20].

To overcome these disadvantages, modular multilevel inverters (MMLI) are developed [21, 22] with two parts viz. level generator and polarity changer. Level generator creates unipolar multilevel output voltage waveforms using high frequency switches and polarity changer converts this unipolar waveform into a bipolar waveform using low frequency switches at line frequency. In this MMLI, the number of switches, conduction loss and switching loss are reduced compared to that of the conventional multilevel inverter for 
the same output levels [23]. Thus, the modular multilevel inverter is employed in the proposed system to feed the PV array power to the utility grid. The contributions of the proposed grid tied PV system are summarized as follows:

$>$ This paper proposes an improved system which employs modular multilevel inverter topology in order to feed PV array generated power to utility grid with lesser number of components and reduced losses.

$>$ The proposed inverter operates with lesser voltage and current THD in order to facilitate smooth grid integration of the system.

\section{WORKING OF THE PROPOSED GRID CONNECTED SYSTEM}

The block diagram of the proposed system shown in Figure 1 consists of PV array, modular multilevel inverter, controller and utility grid. Basic unit structure of MMLI shown in Figure 2(a) consists of Level generator and Polarity changer. This basic unit structure can be expanded to the modular structure as shown in Figure 2(b) to increase the number of output voltage levels. The level generator of the MMLI basic unit consists of $3 \mathrm{PV}$ array sources, $\mathrm{V}_{\mathrm{PV} 1}, \mathrm{~V}_{\mathrm{PV} 2}$ and $\mathrm{V}_{\mathrm{PV} 3}$ and 4 power switches, $\mathrm{S}_{1}, \mathrm{~S}_{2}, \mathrm{~S}_{3}$ and $\mathrm{S}_{4}$. The polarity changer is an H-bridge inverter consisting of 4 switches, $\mathrm{S}_{5}, \mathrm{~S}_{6}, \mathrm{~S}_{7}$ and $\mathrm{S}_{8}$. The controller in the proposed system generates the gate pulses to the switches of level generator to produce a unipolar staircase waveform and generates the gate pulses to the polarity changer switches to convert the unipolar signal into a bipolar signal. Basic structure of MMLI with 3 symmetrical voltage sources generates the output waveform with seven levels of equal widths. The switching of level generator is explained in this section for different voltage levels.

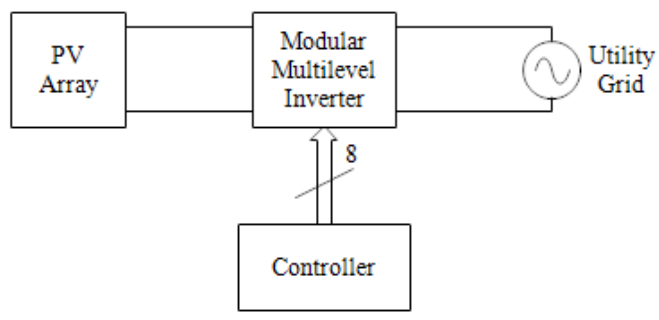

Figure 1. Block diagram of the proposed system

\subsection{Level 0}

In this level, all the switches in the level generator are in OFF condition and the switches, $\mathrm{S}_{5}$ and $\mathrm{S}_{7}$ are $\mathrm{ON}$ in the polarity changer resulting a zero level output and hence, there is no flow of current in the system. The equivalent circuit for this level is shown in Figure 3(a).

\subsection{Level 1}

In this level, switches $\mathrm{S}_{4}, \mathrm{~S}_{5} \& \mathrm{~S}_{8}$ are turned ON, keeping other switches OFF and the dc voltage, $\mathrm{V}_{\mathrm{PV} 3}$ appears across the output terminal and the current flows from $\mathrm{V}_{\mathrm{PV} 3}$ to the output terminals through the path $\mathrm{S}_{5}, \mathrm{~S}_{8}$ and $\mathrm{S}_{4}$ as shown in Figure 3(b).

\subsection{Level 2}

Switches $\mathrm{S}_{2}, \mathrm{~S}_{3}, \mathrm{~S}_{5}$ and $\mathrm{S}_{8}$ are turned $\mathrm{ON}$ and the other switches are turned OFF in this level. As a result, the inverter output voltage terminal is $\left(\mathrm{V}_{\mathrm{PV} 2}+\mathrm{V}_{\mathrm{PV} 3}\right)$. The current flows from $\mathrm{V}_{\mathrm{PV} 2}$ and $\mathrm{V}_{\mathrm{PV} 3}$ to the output terminal through the path $\mathrm{S}_{2}, \mathrm{~S}_{3}, \mathrm{~S}_{5}$ and $\mathrm{S}_{8}$ as shown in Figure 3(c).

\subsection{Level 3}

Switches $\mathrm{S}_{1}, \mathrm{~S}_{5} \& \mathrm{~S}_{8}$ are turned $\mathrm{ON}$, keeping other switches OFF in this level. As shown in Figure 3(d), ( $\left.\mathrm{V}_{\mathrm{PV} 1}+\mathrm{V}_{\mathrm{PV} 2}+\mathrm{V}_{\mathrm{PV} 3}\right)$ appears across output terminal of the inverter and the current flows from $\mathrm{V}_{\mathrm{PV} 1}, \mathrm{~V}_{\mathrm{PV} 2}$ and $\mathrm{V}_{\mathrm{PV} 3}$ to the output terminal through the switches $\mathrm{S}_{1}, \mathrm{~S}_{5}$ and $\mathrm{S}_{8}$.

After achieving the peak voltage of $\left(\mathrm{V}_{\mathrm{PV} 1}+\mathrm{V}_{\mathrm{PV} 2}+\mathrm{V}_{\mathrm{PV} 3}\right)$, the voltage levels are gradually decreased from level 3 to level 0 to generate seven level output voltage waveform at input terminals of polarity changer with step voltages of $0, \mathrm{~V}_{\mathrm{PV} 3},\left(\mathrm{~V}_{\mathrm{PV} 2}+\mathrm{V}_{\mathrm{PV} 3}\right),\left(\mathrm{V}_{\mathrm{PV} 1}+\mathrm{V}_{\mathrm{PV} 2}+\mathrm{V}_{\mathrm{PV} 3}\right),\left(\mathrm{V}_{\mathrm{PV} 2}+\mathrm{V}_{\mathrm{PV} 3}\right), \mathrm{V}_{\mathrm{PV} 3}$ and 0 . The polarity changer switches, $S_{6}$ and $S_{7}$ are turned $O N$ and $S_{5} \& S_{8}$ are turned OFF to change the polarity of this dc link 
voltage, $\mathrm{V}_{\text {dclink }}$ resulting in an alternating periodic stair-case waveform as shown in Figure 4 and the corresponding switching states of the MMLI are shown in Table 1. The number of output levels increases with the increase in number of this basic unit of MMLI.

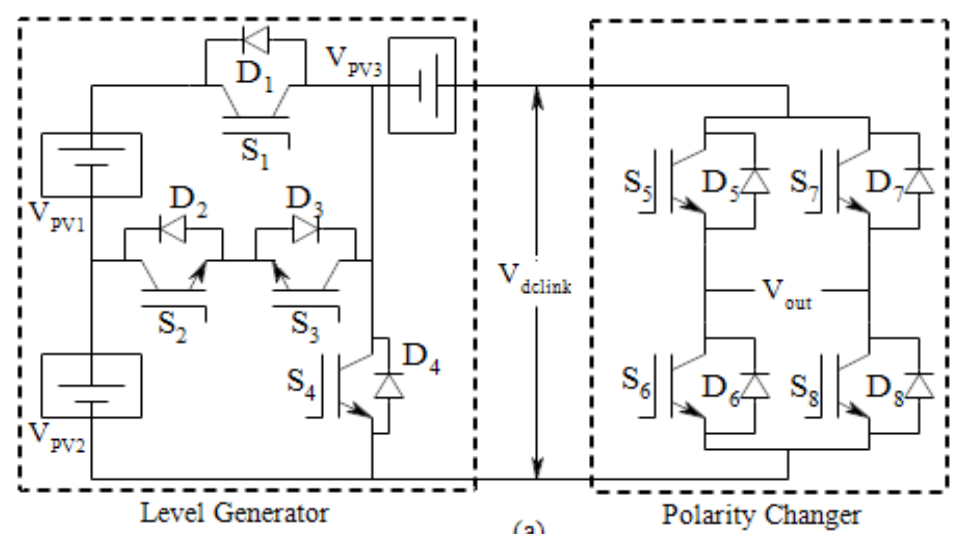

(a)

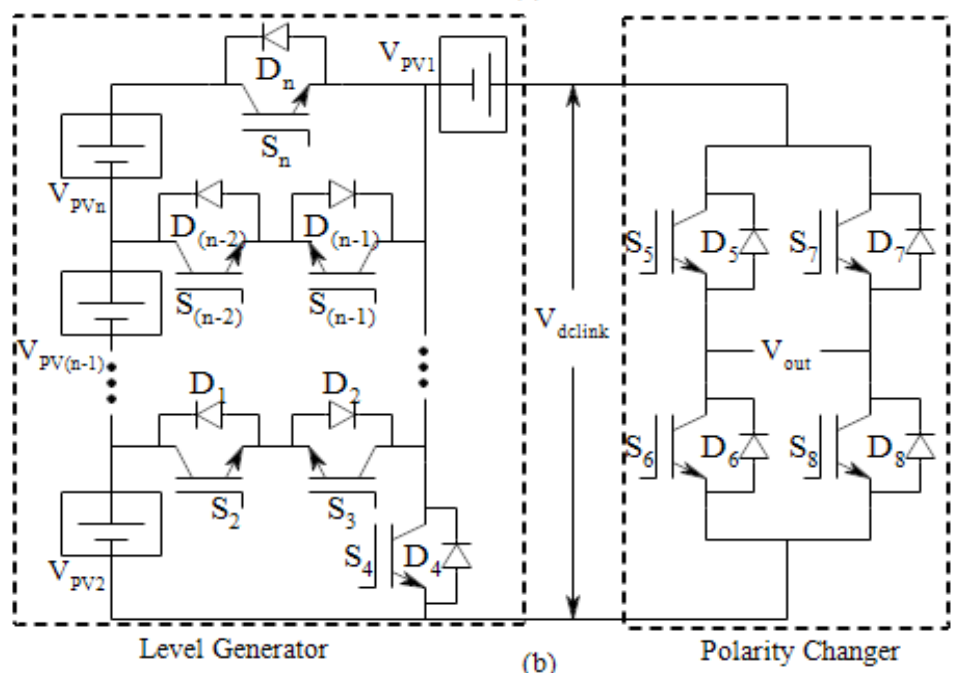

Figure 2. Schematic diagram of MLI (a) Basic unit structure (b) Modular structure

Table 1. Switching States of MMLI

\begin{tabular}{lllllllll}
\hline $\mathbf{S}_{1}$ & $\mathbf{S}_{2}$ & $\mathbf{S}_{3}$ & $\mathbf{S}_{4}$ & $\mathbf{S}_{5}$ & $\mathbf{S}_{6}$ & $\mathbf{S}_{7}$ & $\mathbf{S}_{8}$ & $\mathbf{V}_{\text {out }}$ \\
\hline OFF & OFF & OFF & ON & ON & OFF & OFF & ON & $\mathrm{V}_{\mathrm{PV} 3}$ \\
OFF & ON & ON & OFF & ON & OFF & OFF & ON & $\left(\mathrm{V}_{\mathrm{PV} 2}+\mathrm{V}_{\mathrm{PV} 3}\right)$ \\
ON & OFF & OFF & OFF & ON & OFF & OFF & ON & $\left(\mathrm{V}_{\mathrm{PV} 1}+\mathrm{V}_{\mathrm{PV} 2}+\mathrm{V}_{\mathrm{PV} 3}\right)$ \\
OFF & OFF & OFF & OFF & ON & OFF & ON & OFF & 0 \\
OFF & OFF & OFF & ON & OFF & ON & ON & OFF & $-\mathrm{V}_{\mathrm{PV} 3}$ \\
OFF & ON & ON & OFF & OFF & ON & ON & OFF & $-\left(\mathrm{V}_{\mathrm{PV} 2}+\mathrm{V}_{\mathrm{PV} 3}\right)$ \\
ON & OFF & OFF & OFF & OFF & ON & ON & OFF & $-\left(V_{\mathrm{PV} 1}+\mathrm{V}_{\mathrm{PV} 2}+\mathrm{V}_{\mathrm{PV} 3}\right)$ \\
\hline
\end{tabular}




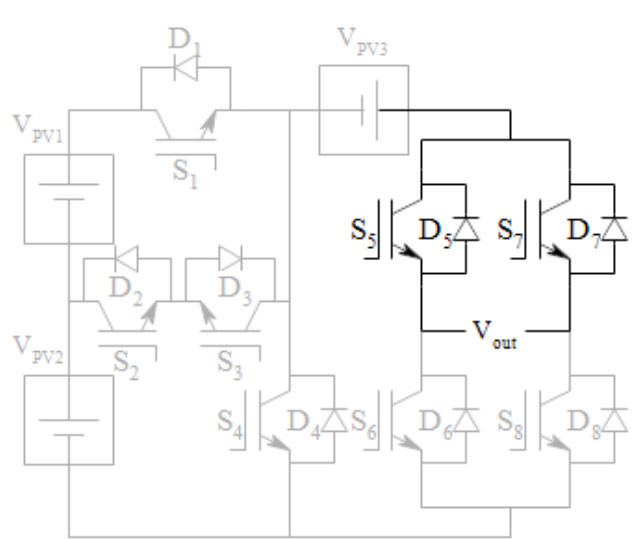

(a)

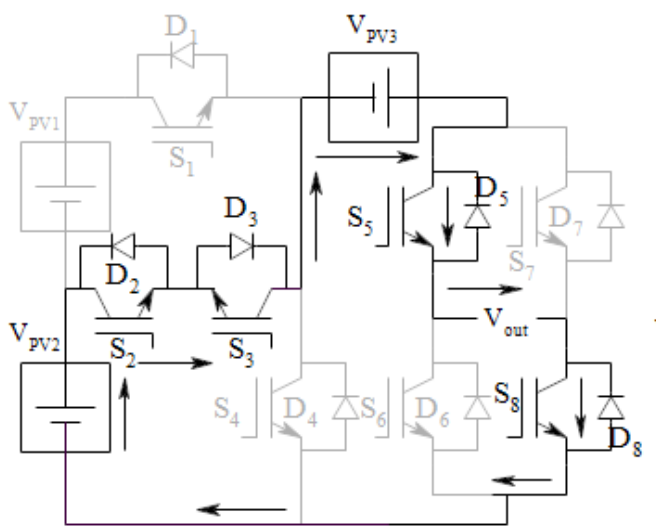

(c)

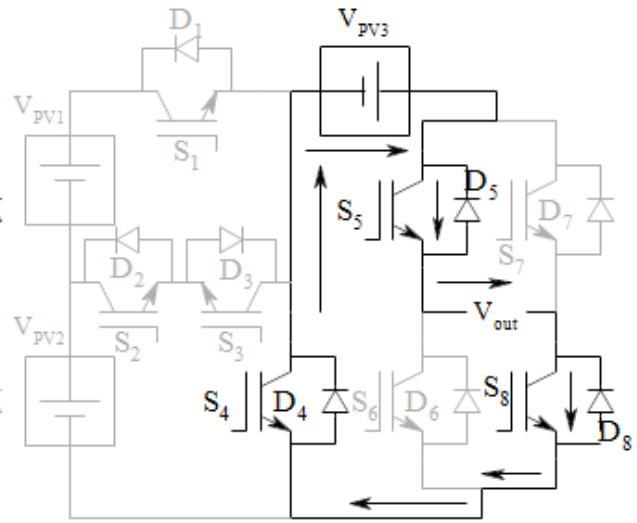

(b)

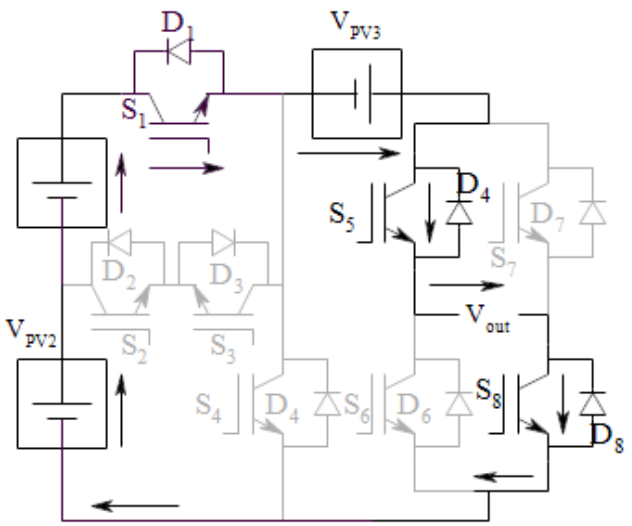

(d)

Figure 3. Equivalent circuit of MMLI basic unit for (a) level 0; (b) level 1; (c) level 2; (d) level 3

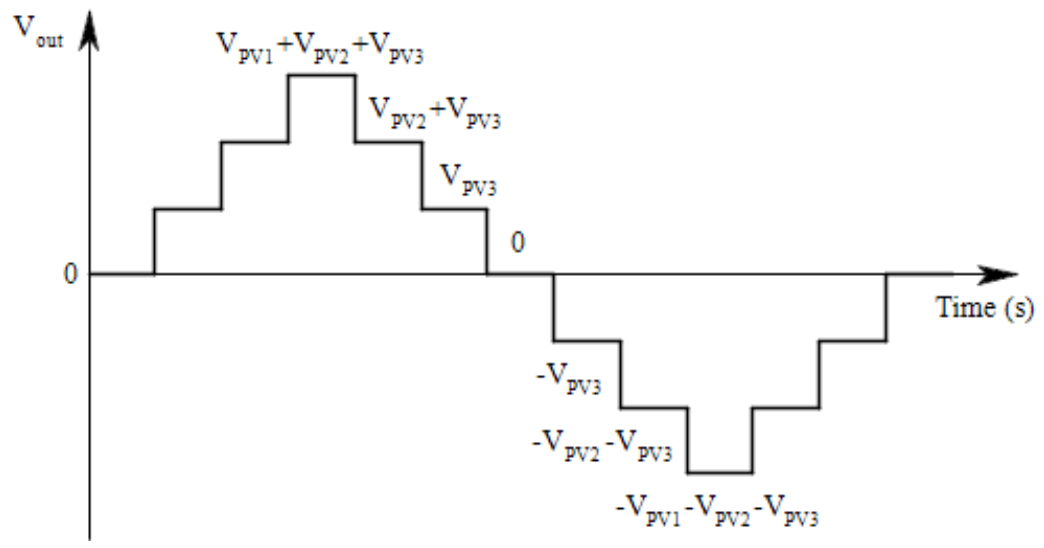

Figure 4. Output voltage waveform of MMLI basic unit

\section{SIMULATION STUDIES}

Simulation model of the proposed system shown in Figure 5 is constructed using power MOSFET switches, pulse generator and utility grid available in the SimPowerSystem Blockset library of MATLAB/simulink software and PV array is modeled using the classical equation as follows [24]:

Int J Pow Elec \& Dri Syst Vol. 10, No. 4, Dec 2019 : 2013 - 2020 


$$
I_{P V}=I_{P h}-I_{0}\left[\exp \left(\frac{V_{P V}+R_{s e} I_{P V}}{V(t h)}\right)-1\right.
$$

where, $I_{p h}$ is the light generated current, $I_{0}$ is the reverse saturation current of the PV array, $R_{\text {se }}$ is the series resistance of the PV array and $\mathrm{V}(\mathrm{th})$ is the thermal voltage.

The proposed 7 level system is simulated with the symmetrical PV array sources at an irradiation of $900 \mathrm{~W} / \mathrm{m}^{2}$ (each source is constituted with 2 series connected PV modules each rated $250 \mathrm{~W}$ with open circuit voltage, $\mathrm{V}_{\mathrm{oc}}$ of $37.8 \mathrm{~V}$ and short circuit current, $\mathrm{I}_{\mathrm{sc}}$ of $8.8 \mathrm{~A}$ ). Figure 6 shows the waveforms of PV array voltages, $\mathrm{V}_{\mathrm{PV} 1}, \mathrm{~V}_{\mathrm{PV} 2} \& \mathrm{~V}_{\mathrm{PV} 3}$ of $62.08 \mathrm{~V}, 61.96 \mathrm{~V} \& 62.82 \mathrm{~V}$ respectively and the generated dc link voltage, $\mathrm{V}_{\text {dclink }}$ of $85.14 \mathrm{~V}$ and dc link current, $\mathrm{I}_{\text {dclink }}$ of $5.33 \mathrm{~A}$.

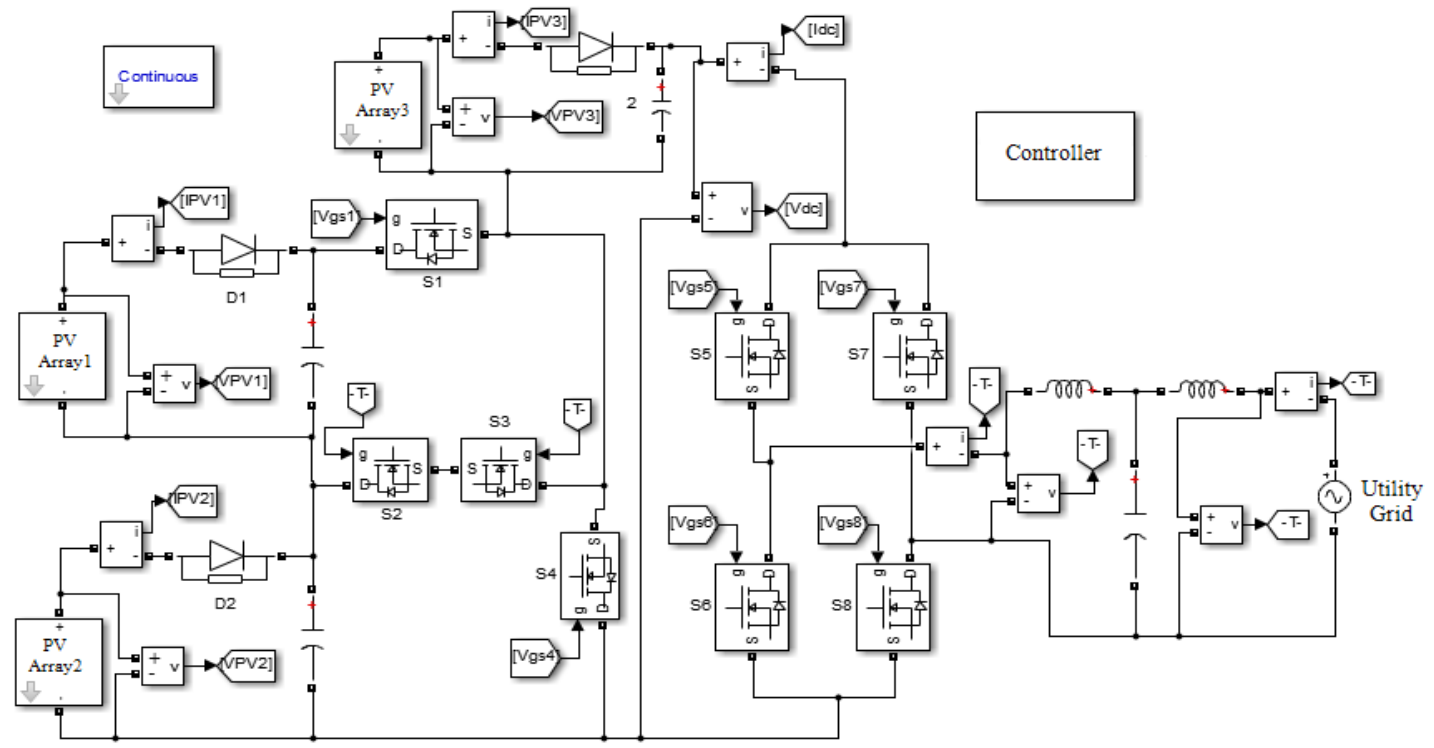

Figure 5. Simulation model of the proposed system
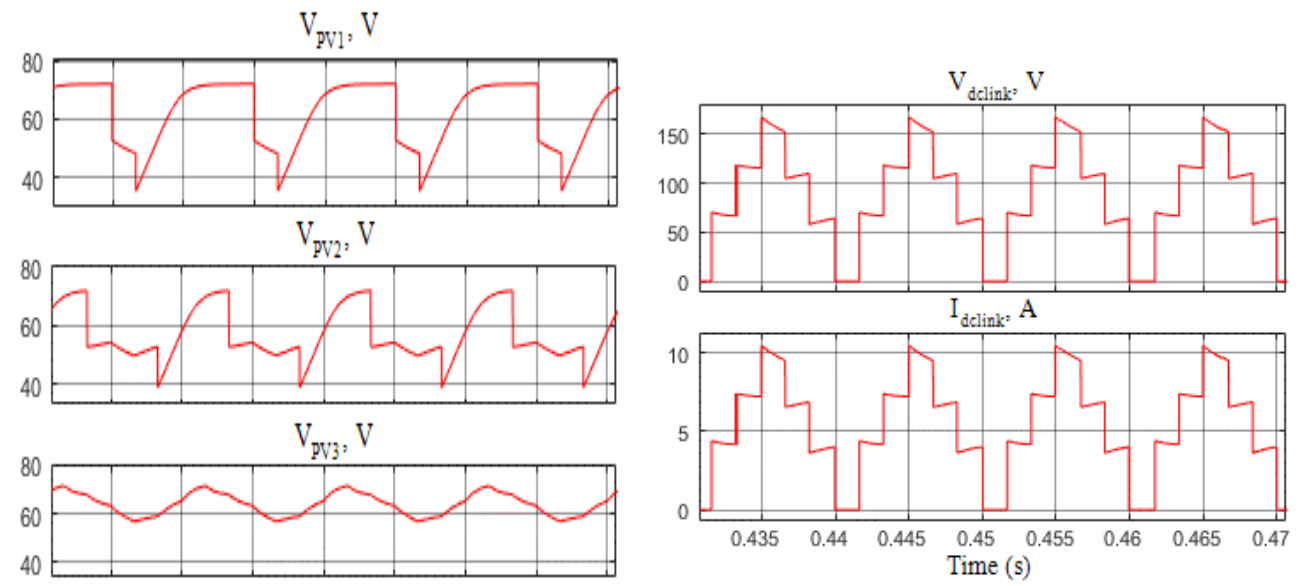

Figure 6. Waveforms of PV array voltages and dc link voltage and current

Unipolar de link voltage is converted into a 7 level stepped bipolar ac voltage by the H-bridge polarity changer and this stepped waveform is filtered using LCL filter of $85 \mu \mathrm{H}$ and $125 \mu \mathrm{F}$ and fed to the $110 \mathrm{~V}$ single phase utility grid. Waveforms of dc link voltage, 7 level inverter output voltage, $\mathrm{V}_{\text {out, }}$ grid voltage, $V_{\text {grid }}$ and grid current, $I_{\text {grid }}$ is shown in Figure 7. The total harmonic distortion (THD) of inverter

Grid tied PV system using modular multilevel inverter (Sujitha N.) 
output voltage and current without filter is found to be $22.16 \%$ and $2.7 \%$ and THD of the grid voltage and current with filter is reduced to $1.74 \%$ and $2.18 \%$ respectively which is well within the IEEE 519 standard as shown in Figure 8.

The proposed system is simulated and analyzed for various irradiation conditions of PV array and the corresponding power fed to the grid and efficiency is plotted in Figure 9. From Figure 9, it is evident that the grid power and efficiency is increasing with the increase in PV array irradiations. Thus, modular multilevel inverter topology feed the maximum power to the utility grid from the PV array efficiently at higher irradiation conditions with low voltage and current THD.

A comparsion between the components count of the existing topologies and the modular multilevel inverter toplogy presented in this paper are provided in Table 2. From the table, it is evident that the modular multilevel toplogy presented in this paper has less number of components which reduces the cost and size of the system.
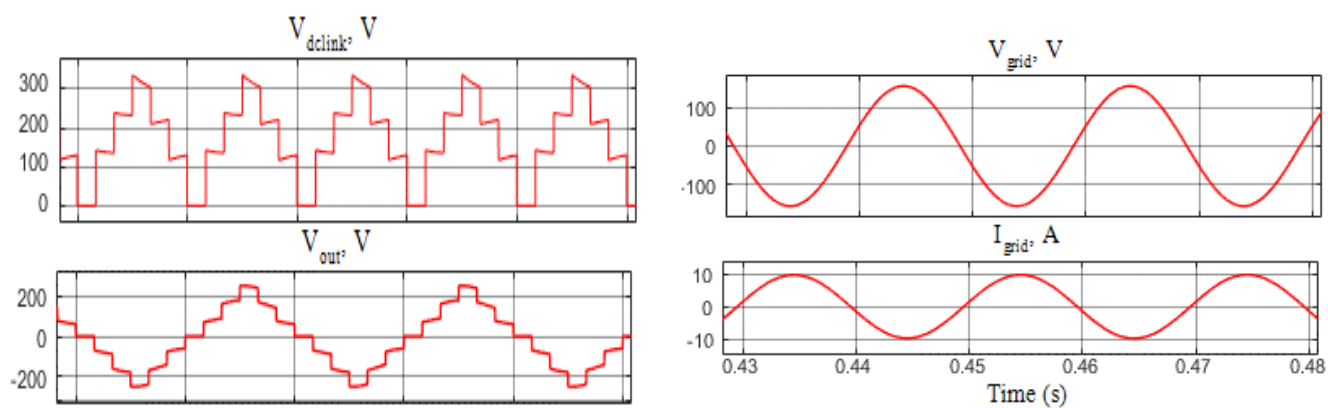

Figure 7. Waveforms of dc link voltage, $\mathrm{V}_{\mathrm{dclink}}$, output voltage without filter, $\mathrm{V}_{\text {inv }}$, grid voltage, $\mathrm{V}_{\text {grid }}$ and grid current, $I_{\text {grid }}$

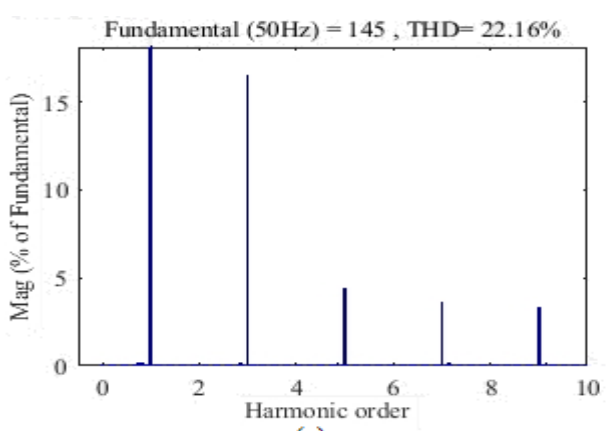

(a)

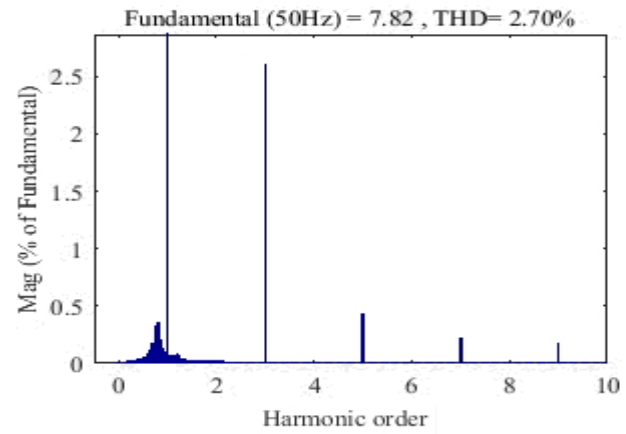

(b)

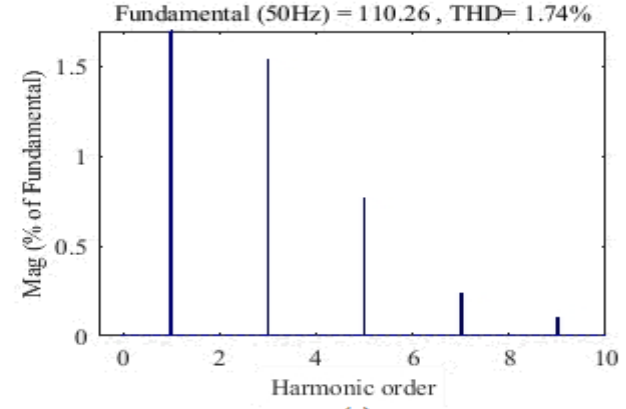

(c)

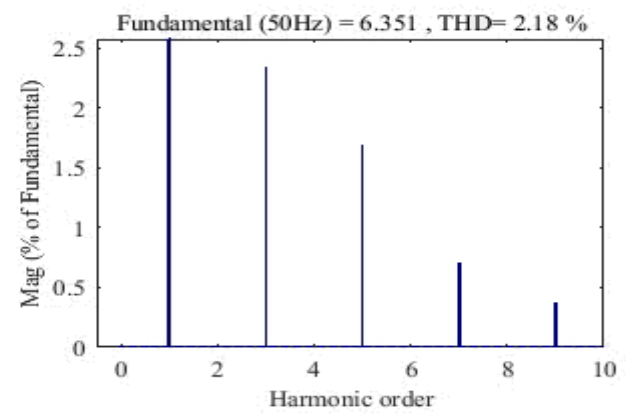

(d)

Figure 8. THD waveforms of (a) grid voltage without filter (b) grid current without filter (c) grid voltage with filter (d) grid current with filter 


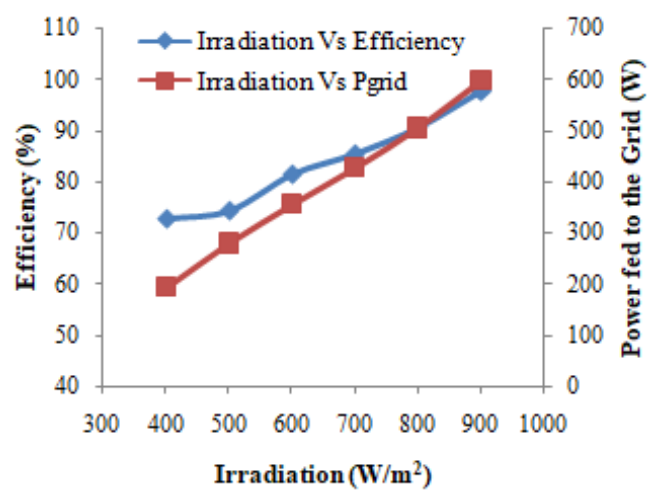

Figure 9. Relative variation of output power and efficiency of the proposed system with respect to PV array irradiations

Table 2. Comparison of seven level topologies

\begin{tabular}{cccccc}
\hline Topology & $\begin{array}{c}\text { Diode } \\
\text { clamped } \\
\text { MLI }\end{array}$ & $\begin{array}{c}\text { Capacitor } \\
\text { clamped MLI }\end{array}$ & $\begin{array}{c}\text { Cascaded H- } \\
\text { bridge MLI }\end{array}$ & $\begin{array}{c}\text { Reverse } \\
\text { voltage MLI } \\
{[25]}\end{array}$ & $\begin{array}{c}\text { Proposed } \\
\text { Modular } \\
\text { MLI }\end{array}$ \\
\hline Components & 1 & 1 & 3 & 3 & 3 \\
Sources & 16 & 0 & 0 & 0 & 0 \\
Capacitors & 0 & 16 & 0 & 0 & 0 \\
Switches & 12 & 12 & 12 & 10 & 8 \\
\hline
\end{tabular}

\section{CONCLUSION}

Grid tied photovoltaic system using modular multilevel inverter is proposed in this paper. MMLI used in the proposed system produces a 7 level output with minimum number of switches active at any instant. Generation of output levels are explained with the corresponding equivalent circuit in this paper. MATLAB/Simulink software is used for the simulation analysis of the proposed system and the results are furnished. From the simulation results, it is evident that the proposed system is capable of feeding power to grid from the symmetrical PV array sources with low voltage and current THD of $1.74 \%$ and $2.18 \%$ respectively. The number of output levels can also be increased, if more number of basic units of this MMLI is added.

\section{ACKNOWLEDGEMENTS}

The authors would like to thank Mr. Swithin Abner, Mr. Sumit Panja and Mr. Rishi Raj Gupta, B.Tech. Students, School of Electrical Engineering, Vellore Institute of Technology, Chennai, India for their contributions in the simulation study of stand-alone modular multilevel inverter.

\section{REFERENCES}

[1] N.T.,Zhang C., Mahmud M.A., "Optimal Coordination of G2V and V2G to Support Power Grids with High Penetration of Renewable Energy," IEEE Trans. Transp. Electrif., vol. 1, pp.188-195, 2015.

[2] D. Sattianadan, K. Saravanan, S. Murugan, N. Hari, P. Venkadesh, "Implementation of quasi-z source inverter for grid connected PV based charging station of electric vehicle," International Journal of Power Electronics and Drive System, vol. 10, no. 1, pp. 366-373, March 2019.

[3] Basmadjian R., Meer H, "A Heuristics-Based Policy to Reduce the Curtailment of Solar-Power Generation Empowered by Energy-Storage Systems,” Electronics, Vol. 7, no.12, pp. 349, Nov. 2018.

[4] S. Nagaraja Rao, D. V. Ashok Kumar, Ch. Sai Babu, "Grid Connected Distributed Generation Systemwith High Voltage Gain Cascaded DC-DC Converter Fed Asymmetric Multilevel Inverter Topology", International Journal of Electrical and Computer Engineering (IJECE), vol. 8, no.6, pp. 4047-4059, December 2018.

[5] S. Krithiga, N. Ammasai Gounden, "An Improved Power Electronic Controller with Unity Power Factor for a Single-Stage Grid-Tied PV System”, Arab Journal Sci. Engg., vol. 39, pp.7173-7182, 2014.

[6] K. Rajasekhara Reddy, V. Nagabhaskar Reddy, M. Vijaya Kumar, "Control of Single Stage Grid Tied Photovoltaic Inverter Using Incremental Conductance Method," International Journal of Power Electronics and Drive System, vol. 9, no. 4, pp. 1702-1708, December 2018. 
[7] H. E. Gelani and F. Dastgeer, "Efficiency Analyses of a DC Residential Power Distribution System for the Modern Home," Adv. Electr.Comput.Eng., vol. 15, no. 1, pp. 135-142, 2015.

[8] Krithiga S., Ammasai Gounden N., "Investigations of an improved PV system topology using multilevel boost converter and line commutated inverter with solutions to grid issues", Simulation Modelling Practice and Theory, vol. 42, pp. 147-159, 2014.

[9] Mario Norman Syah and Subiyanto Subiyanto, "Performance enhancement of maximum power point tracking for grid-connected photovoltaic system under various gradient of irradiance changes," TELKOMNIKA Telecommunication, Computing, Electronics and Control, vol. 17, no. 4, August 2019.

[10] Bhagwat P.M., Stefanovic V.R., "Generalized Structure of a Multilevel PWM Inverter," IEEE Trans. Ind. Appl., IA-19, pp. 1057-1069, 1983.

[11] Carrara G., Gardella S., Marchesoni M., Salutari R., Sciutto G., "A new multilevel PWM method: a theoretical analysis," IEEE Trans. Power Electron., vol. 7, pp. 497-505, 1992.

[12] Beigi L.M.A., Azli N.A., Khosravi F., Najafi E., Kaykhosravi A., "A new multilevel inverter topology with reduced number of power switches," in Proceedings of the 2012 IEEE International Conference on Power and Energy (PECon); IEEE, pp. 55-59, 2012.

[13] M. Khanfara, R. El Bachtiri, M.Boussetta, K. El Hammoumi, “A Multicarrier PWM Technique for Five Level Inverter Connected to the Grid," International Journal of Power Electronics and Drive System, vol. 9, no. 4, pp. 1774-1783, Deecember 2018.

[14] K. Yanmaz, I. H. Altas, and O. O. Mengi, "Five level cascaded H-Bridge D-STATCOM using a new fuzzy and PI controllers model for wind energy systems," Adv. Electr. Comput. Eng., vol. 17, no. 4, pp. 49-58, 2017.

[15] M. Rasheed, R. Omar, M. Sulaiman, W. A. Halim, "Particle swarm optimisation (PSO) algorithm with reduced Number of switches in multilevel inverter (MLI)," Indonesian Journal of Electrical Engineering and Computer Science. vol. 14, no. 3, pp. 1114-1124, June 2019.

[16] N. Devarajan, A. Reena. "Reduction of switches and DC sources in Cascaded Multilevel Inverter," Bulletin of Electrical Engineering and Informatics, vol. 4, no.3, pp. 186-195, September 2015.

[17] Hasan M.M. Abu-Siada A., Dahidah M.S.A. "A three-phase symmetrical DC-Link multilevel inverter with reduced number of DC Sources," IEEE Trans. Power Electron., vol. 33, pp. 8331-8340, 2018.

[18] Gupta K.K., Ranjan A., Bhatnagar P., Sahu L.K., Jain S, "Multilevel Inverter Topologies with Reduced Device Count: A Review,” IEEE Trans. Power Electron. vol. 31, pp. 135-151, 2016.

[19] Prabaharan N., Palanisamy K., "A comprehensive review on reduced switch multilevel inverter topologies, modulation techniques and applications,” Renew. Sustain. Energy Rev., vol. 76, pp. 1248-1282, 2017.

[20] Gaddala Jayaraju and Gudapati Sambasiva Rao, "Intelligent controller based power quality improvement of microgridintegration of photovoltaic power system using new cascade multilevel inverter," International Journal of Electrical and Computer Engineering (IJECE), vol. 9, no. 3, pp. 1514-1523, June 2019.

[21] B. Zhang, C. Zhao, C. Guo, X. Xiao, and L. Zhou, "Controller architecture design for MMC-HVDC," Adv. Electr.Comput.Eng., vol. 14, no. 2, pp. 9-16, 2014.

[22] D. Petreus, S. Daraban, and M. Cirstea, "Modular hybrid energy concept employing a novel control structure based on a simple analog system," Adv. Electr. Comput. Eng., vol. 16, no. 2, pp. 3-10, 2016.

[23] Samsami H., Taheri A., Samanbakhsh R., "New bidirectional multilevel inverter topology with staircase cascading for symmetric and asymmetric structures," IET Power Electron., vol. 10, pp.1315-1323, 2017.

[24] Krithiga, S., Gounden N.G.A., "Power electronic configuration for the operation of PV system in combined gridconnected and stand-alone modes," IET Power Electron., vol. 7, pp. 640-647, 2014.

[25] E. Najafi and A. H. M. Yatim, "Design and Implementation of a New Multilevel Inverter Topology," IEEE Transactions on Industrial Electronics, vol. 59, no. 11, pp. 4148-4154, Nov. 2012. 